\title{
Хірургічна корекція рівня адипокінів та греліну в щурів із метаболічним синдромом
}

\begin{abstract}
Мета роботи: дослідити рівень адипокінів та греліну в організмі піддослідних тварин із модельованим метаболічним синдромом після проведеної хірургічної корекції різними типами баріатричних втручань.

Матеріали і методи. Дослідження проведено на 40 білих щурах-самцях лінії Wistar масою 200-250 г (вік 9-10 тижнів), яких утримували в стандартних умовах віварію. Щурів основної групи (n=56) утримували на дієті з високим вмістом жиру (понад 60 \% енергії від жирів) впродовж 16 тижнів. Після цього їх розділили на групи за типом операційного втручання: слівгастректомія, шунтування шлунка за Ру, лігування лівої шлункової артерії. В післяопераційний період (14 днів та 1 місць) оцінено концентрацію адипонектину, лептину та греліну.

Результати досліджень та їх обговорення. Хірургічне лікування ожиріння знижує рівень греліну та лептину та підвищує рівень адипонектину у всіх дослідних групах тварин із змодельованим метаболічним синдромом. Однак у групі щурів, яким проводили лігування лівої шлункової артерії, операційне втручання, нормалізація рівня адипокінів (лептину та адипонектину) та рівня греліну було найкращим та статистично достовірним відносно метаболічного синдрому групи як на 14-ту добу, так і через 1 місяць після операційного втручання за всіма порівнювальними показниками $(\mathrm{p}<0,05)$.
\end{abstract}

Ключові слова: баріатричні втручання; грелін; лептин; адипонектин; метаболічний синдром.

Постановка проблеми і аналіз останніх досліджень та публікацій. Метаболічний синдром (МС) являє собою одну з найбільш вагомих проблем сучасної медицини, оскільки $є$ причиною суттєвої інвалідизації та смертності. Поширення МС настільки високе, що ВООЗ визначила його як неінфекційну епідемію, адже за даними літератури його діагностують від 8 до 67 \% [11]. Така велика варіація залежить від комбінації генетичних, біологічних (вік, стать, етнічна приналежність) i соціальних факторів (урбанізація, рівень освіти, соціально-економічний статус), а також від відсутності загальноприйнятих критеріїв, що визначають власне МС.

Все це зумовлює пошук ефективних і безпечних методів зниження зайвої маси тіла. Програма лікування МС включає дієтотерапію, збільшення фізичної активності, психо- та фармакотерапію [7]. Проте ефективність терапевтичних підходів тимчасова та низька. Тому розробка ефективних, щадних та маловартісних методів лікування МС залишається актуальним питанням і спроби знайти так звані предиктори відповіді виконуються в багатьох наукових центрах.

На сьогодні баріатрична хірургія $є$ одним 3 ефективних методів лікування МС, що допомагає позбутися не тільки надлишкової маси тіла на тривалий час, але й нормалізувати вуглеводний обмін, покращити ліпідний спектр та рівень артеріального тиску, що в сукупності дає змогу покращити якість життя пацієнта $[9,14]$.
Однією $з$ найпоширеніших комбінованих баріатричних операцій є лапароскопічне гастрошунтування (ГШ), яке поєднує рестриктивний i шунтувальний компоненти [8]. Ще одним методом хірургічного лікування МС $є$ лапароскопічна сліврезекція (ЛСР), або гастроплікація, яка стала улюбленим хірургічним методом лікування МС у більшості країнах завдяки своїй доступній вартості, безпеці й ефективності [4].

Згідно 3 існуючою літературою, вплив баріатричних процедур на рівень греліну в плазмі різноманітний. Встановлено, що ЛСР спричиняє зниження рівня греліну в багатьох дослідженнях за останні десять років. Ймовірно, це результат резекції дна шлунка, де відбувається більша частина продукції греліну [15]. В останні роки популярності набуває метод хірургічного лікування емболізація лівої шлункової артерії, ефективність якої вже доведена кількома роботами $[10,12,17]$.

Втім триває дискусія стосовно предикторної цінності орексигенних гормонів, зокрема, греліну в зниженні маси тіла. У пацієнтів із МС його концентрація може бути знижена, що вірогідно зумовлено адаптивними механізмами у відповідь на надлишкову масу тіла. До анорексигенних гормонів належить лептин та адипонектин, які за своєю природою є пептидами і продукуються адипоцитами. Концентрація адипонектину знижується при ожирінні на відміну від лептину, концентрація якого в сироватці крові прямопропорційна масі жирової тканини [3, 6, 16]. Лептин у нормі 
стимулює центр насичення і гальмує центр голоду в гіпоталамусі, підвищення його рівня забезпечує відчуття ситості під час їжі. У людей з МС спостерігається гіперлептинемія, проте його ефекти знижені внаслідок резистентності.

Таким чином, на сьогодні триває дискусія стосовно вибору хірургічного методу лікування хворих із МС, враховуючи гормональні впливи орексигенних та анорексигенних гормонів.

Мета роботи: дослідити рівень адипокінів та греліну в організмі піддослідних тварин із модельованим метаболічним синдромом після проведеної хірургічної корекції різними типами баріатричних втручань.

Матеріали і методи. Дослідження проводено на 40 білих щурах-самцях лінії Wistar масою 200250 г (вік 9-10 тижнів), яких утримували в стандартних умовах віварію (температура повітря: $(22 \pm 2){ }^{\circ} \mathrm{C}$, вологість - 30-60\%, світлий/темний цикл: 12/12 год). Самців щурів контрольної групи $(n=8)$ утримували на звичайній контрольній дієті. Щурів-самців основної групи $(n=56)$ утримували на дієті з високим вмістом жиру (ВВЖ) (понад 60 \% енергії від жирів) впродовж 16 тижнів [13], таким чином моделюючи в них розвиток МС. Після впливу дієти з високим вмістом жиру впродовж 16 тижнів щурів у когорті ВВЖ випадково розподіляли до ВВЖ без хірургічного втручання $(\mathrm{n}=8)$ та групи ВВЖ, які перенесли відповідну операцію $(n=48)$.

При проведенні експерименту дотримувалися вимог Європейської конвенції про захист хребетних тварин, що використовуються для дослідних та інших наукових цілей (Страсбург, 1986) та Директиви Європейського Союзу 2010/10/63 EU щодо експериментів на тваринах. Комісія з біоетики Тернопільського національного медичного університету імені І. Я. Горбачевського МОЗ України (протокол № 12 від 4 листопада 2020 р.) не виявила порушень морально-етичних норм під час цього дослідження.

Щурів розподілили на 3 групи за типом баріатричної хірургії: слівгастректомія (СГ) $(\mathrm{n}=16)$, шлункове шунтування за Ру (шунтування за Ру) (n=16) та перев’язування лівої шлункової артерії (ЛЛША) (n=16). Усіх щурів голодували на ніч перед операцією. Операції виконували із знеболенням 4 \% внутрішньочеревною ін’єкцією севофлурану.

Для процедури СГ приблизно 75-80 \% шлунка було видалено вздовж великої кривизни від антрального відділу до дна за допомогою вузлових шовкових швів (5-0).
Для шунтування за Ру було виділено шлунковий мішок, що склав приблизно 20 \% загального об’єму шлунка. Зважали, щоб не пошкодити нервову та судинну систему (ліву шлункову артерію) до стравохідно-шлункового з'єднання шлункового мішка. По-друге, порожню кишку перерізали приблизно в 40 см від ілеоцекального клапана ( 40 мм від зв’язки Трейца), а дистальний кінець анастомозували до шлункового мішка. По-третє, проксимальний відрізаний кінець тонкої кишки був анастомозований збоку до тонкої кишки ( 25 мм від ілеоцекального клапана). Ця процедура привела до отримання Ру-петлі завдовжки приблизно 15 мм, загальної петлі завдовжки 25 мм і біліопанкреатичної приблизно 40 мм. Усі анастомози були виконані з використанням вузлових шовкових швів (5-0) з наступним закриттям живота з використанням пролену (3-0).

Під час ЛЛША стравохід відділяли від сполучної тканини елементів на 15-20 мм від точки 3’єднання зі шлунком; ліворуч шлункову артерію перев’ язували шовком 3-0, а потім перерізали.

Після операції щурам негайно робили підшкірні ін'єкції стерильного нормального фізіологічного розчину і вводили рідку дієту впродовж 3-5 днів. У кінці експерименту через 4 тижні після операції тварин декапітували під тіопенталовим наркозом.

У сироватці крові щурів визначали вміст адипонектину. У жировій тканині визначали вміст лептину. Вміст лептину та адипонектину були визначені за допомогою імуноферментного аналізу з використанням наборів “Bio Vendor” (Leptin Mouse/Rat Elisa, Adiponectin HMW Mouse/Rat Elisa) (Чехія). Рівень герліну вимірювали методом імуноферментного аналізу (IФА) за допомогою імуноферментного набору фірми “Diagnostic System Laboratories” (США). Досліджувані показники визначали двічі: на 14-ту добу та через 1 місяць після проведення хірургічних втручань.

Результати досліджень обробляли методом варіаційної статистики 3 використанням t-критерію Ст’юдента.

Результати досліджень та їх обговорення. На сьогодні жирову тканину розглядають як самостійний ендокринний орган, в якому виробляються біологічно активні речовини і гормони адипокіни. До найважливіших відносять лептин, адипонектин, резистин, фактор некрозу пухлин-альфа, інтерлейкін-6. Ступінь метаболічних порушень у хворих із МС залежить не стільки від об’ єму жирової тканини, скільки від гормональної активності клітин - адипоцитів. 
Відомо, що одним із основних протизапальних адипокінів $є$ адипонектин, активність і кількість якого знижується при вісцеральному ожирінні, на відміну від лептину, резистину, інтерлейкінів, фактора некрозу пухлин-альфа. Показано, що зниження експресії адипонектину корелює з інсулінорезистентністю та цукровим діабетом 2 типу [5]. Концентрація адипонектину в сироватці крові зменшується при ожирінні та інсулінорезистентності.

При дослідженні рівня адипонектину в дослідних щурів ми встановили статистично значиме зниження концентрації адипонектину у щурів із змодельованим МC $-4,07 \pm 0,12$ мкг/мл $(\mathrm{p}<0,05)$ порівняно з групою контролю. Проаналізувавши вплив різних типів баріатричних втручань, встановлено підвищення його рівня вже на 14-ту добу у всіх підгрупах операційного втручання. Через 1 місяць констатовано суттєве зростання концентрації адипонектину, особливо у підгрупі СГ та

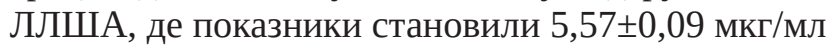
та 6,02 $\pm 0,13$ мкг/мл, відповідно (рис. 1).

Рівень лептину в крові помітно підвищується при ожирінні і позитивно корелює з масою жирової тканини в організмі. У більшості осіб з надлишковою масою тіла $є$ лептинорезистентність, що $€$ результатом порушення передачі сигналу від гормону або порушення його проникнення через гематоенцефалічний бар'єр. Лептинорезистентність, у свою чергу, сприяє розвитку гіперінсулі- немії і посилює інсулінорезистентність, впливає на розвиток порушень обміну глюкози [2].

Під час аналізу рівня лептину у порівнювальних групах ми встановили значне зростання його рівня в щурів з МС порівняно з контрольною групою - на 35,83 \% $(\mathrm{p}<0,05)$. Серед виконаних операційних втручань, ЛЛША продемонструвала найкращий вплив на динаміку зниження рівня лептину на 14 добу та через 1 місць (рис. 2).

Грелін - це нейроендокринний гормон шлунково-кишкового тракту, переважно дна шлунка, який стимулює голодну моторику шлунка, апетит та забезпечує позитивний енергетичний баланс, що супроводжується збільшенням маси тіла. Він $є$ антагоністом лептину, регулює синтез і секрецію нейропептидів гіпоталамусу, які забезпечують регуляцію центрів голоду і насичення нейропептид та агутизв’язаний пептид, стимулюючи відчуття голоду.

При дослідженні рівня греліну у досліджуваних тварин ми встановили зростання його кон-

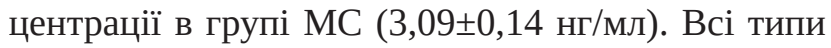
операційних втручань продемонстрували зниження рівня греліну. Втім саме ЛЛША та СГ мали найвираженіший хірургічний вплив на зниження концентрації (рис. 3). Це зумовлено відключенням грелінпродукуючої зони шлунка.

Таким чином, МС супроводжується порушенням балансу багатьох гормонів жирової тканини, які впливають на розвиток інсулінорезистентно-

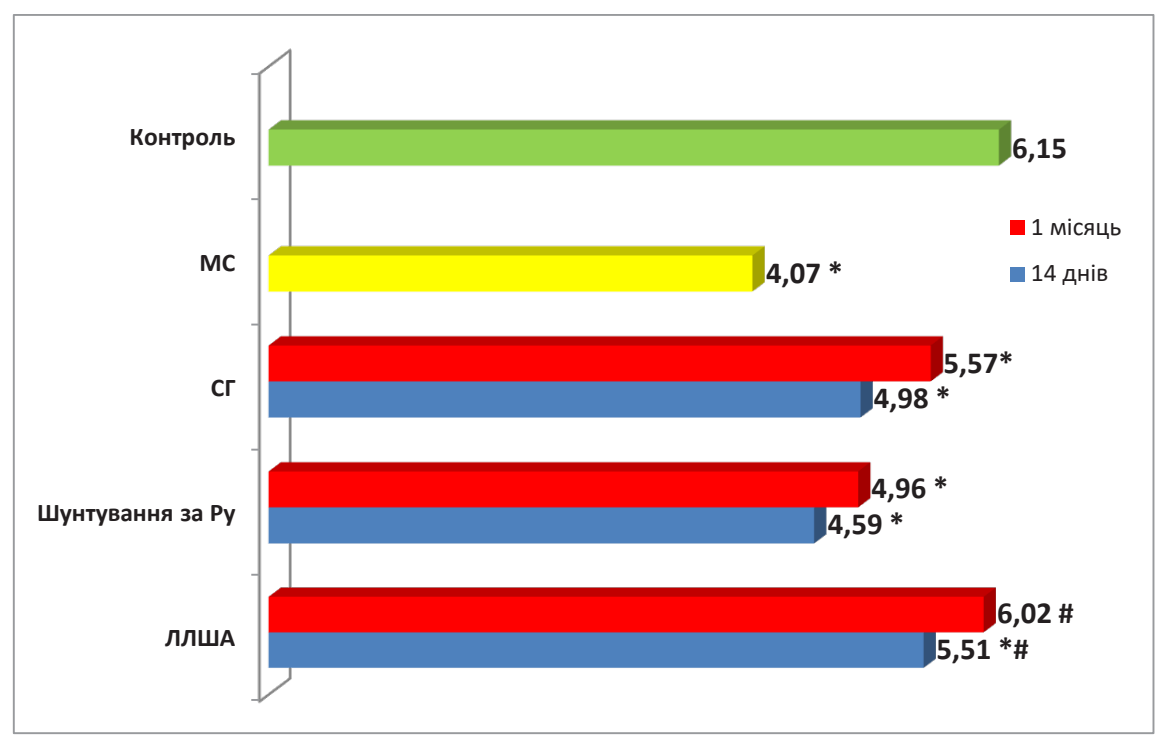

Примітки: *- достовірність різниці із групою контролю;

\# - достовірність різниці із групою із метаболічним синдромом.

Рис. 1. До- та післяопераційний рівень адипонектину (мкг/мл) у крові щурів за умов змодельованого метаболічного синдрому. 


\section{ЕКСПЕРИМЕНТАЛЬНІ ДОСЛІДЖЕННЯ}

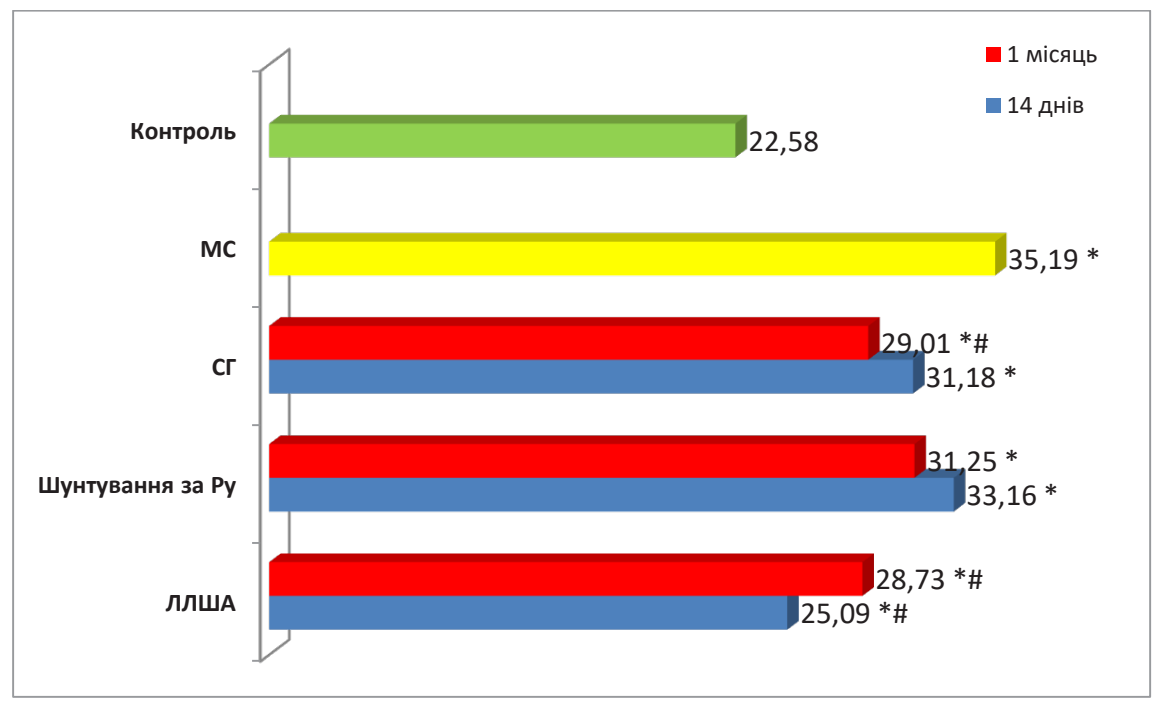

Примітки: * - достовірність різниці із групою контролю;

\# - достовірність різниці із групою із метаболічним синдромом.

Рис. 2. До- та післяопераційний рівень лептину (нг/мл) у крові щурів за умов змодельованого метаболічного синдрому.

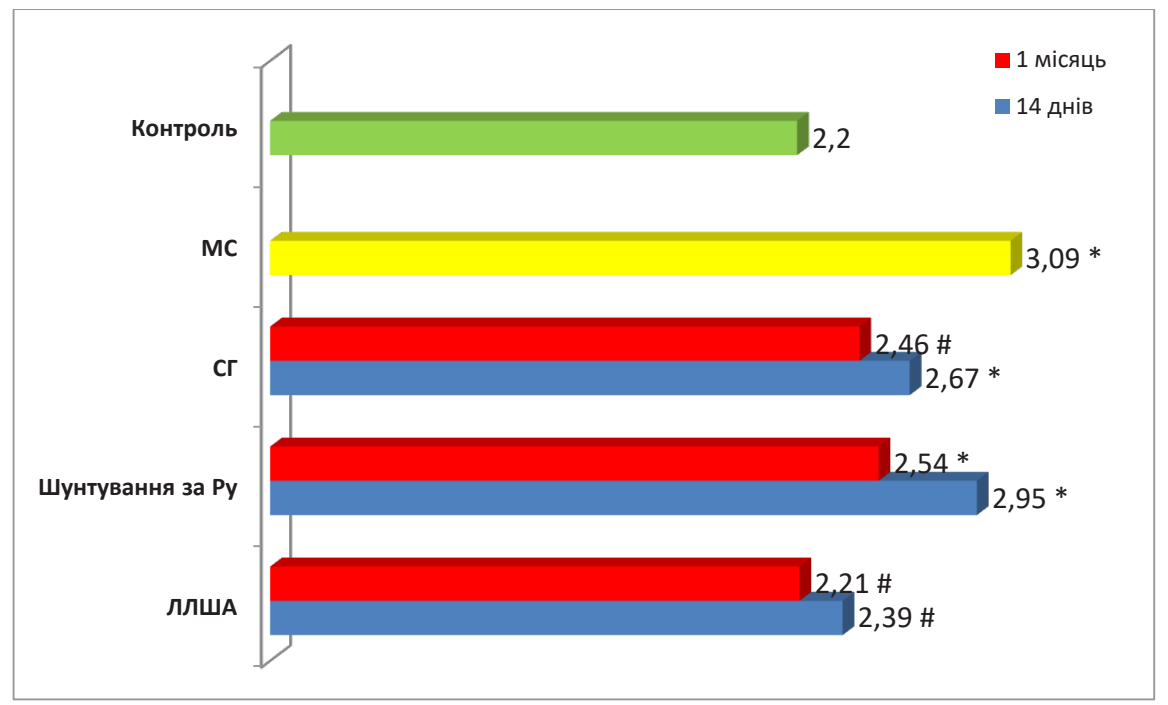

Примітки: *- достовірність різниці із групою контролю;

\# - достовірність різниці із групою із метаболічним синдромом

Рис. 3. До- та післяопераційний рівень греліну (нг/мл) у крові щурів за умов змодельованого метаболічного синдрому.

сті, цукрового діабету 2 типу та артеріальної гіпертензії, що у підсумку впливає на процес атерогенезу, розвиток серцево-судинних захворювань та їх ускладнень [1].

Численні дослідження дають змогу зробити висновок, що нормалізація рівня адипоцитокінів більшою мірою залежить від зниження маси тіла та від типу операції. Нормалізація рівня гормонів жирової тканини після баріатричних операцій знижує ризик атеросклеротичного ураження судинного русла, ризик розвитку ішемічної хвороби серця та артеріальної гіпертензії.

У результаті вивчення впливу баріатричних операцій з різними механізмами дії на рівень греліну та 


\section{ЕКСПЕРИМЕНТАЛЬНІ ДОСЛІДЖЕННЯ}

лептину встановлено високу ефективність рестриктивних втручань (СГ) порівняно з комбінованими та мальабсорбтивними (шунтування за Ру). На рівні $з$ рестриктивними типами ЛЛША продемонструвала найкращі результати в корекції гормонального дисбалансу орексигенних та анорексигенних гормонів.

Висновок. Хірургічне лікування ожиріння знижує рівень греліну та лептину та підвищує рі- вень адипонектину у всіх дослідних групах тварин із змодельованим МС. Однак у групі щурів, яким проводили лігування лівої шлункової артерії, операційне втручання, нормалізація рівня адипокінів (лептину та адипонектину) та рівня греліну було найкращим та статистично достовірним відносно MC групи як на 14-ту добу, так і через 1 місяць після операційного втручання за всіма порівнювальними показниками $(\mathrm{p}<0,05)$.

\section{СПИСОК ЛІТЕРАТУРИ}

1. Бабак О. Я. Гормональні зміни в жировій тканині хворих на гіпертонічну хворобу й ожиріння / О.Я.Бабак, А. О. Андреева // Український терапевтичний журнал. - 2013. - № 1. - C. 63-67.

2. Марусин О. В. Ожиріння та лептинорезистентність / О. В. Марусин, В. І. Боцюрко // Галицький лікарський вісник. - T. 19, № 1. - C. 155-157.

3. Adiponectin in youth, relationship to visceral adiposity, insulin sensitivity, and beta-cell function / F. Bacha, R. Saad, N. Gungor, S. A. Arslanian // Diabetes Care. - 2004. - Vol. 27 (2). P. 547-552.

4. Laparoscopic sleeve gastrectomy: a multi-purpose bariatric operation / A. Baltasar, C. Serra, N. Pérez [et al.] // Obesity Surgery. - 2005. - Vol. 15 (8). - P. 1124-1128.

5. Adiponectin and insulin resistance in obesity-related diseases / H. Ebinc, Z. N. Ozkurt, F. A. Ebinç [et al.] // Journal of International Medical Research. - 2008. - Vol. 36 (1). - P. 71-79.

6. Adiponectin promotes adipocyte differentiation, insulin sensitivity, and lipid accumulation / Y. Fu, N. Luo, R. L. Klein, W. T. Garvey // Journal of Lipid Research. - 2005. - Vol. 46 (7). - P. 1369-1379.

7. Garber A. J. The metabolic syndrome / A. J. Garber // Medical Clinics. - 2004. - Vol. 88 (4). - P. 837-846.

8. (2011). Laparoscopic Roux-en-Y gastric bypass: 10-year follow-up / K. Higa, T. Ho, F. Tercero [et al.] // Surgery for obesity and related diseases. - 2011. - Vol. 7 (4). - P. 516-525.

9. Jia W. Obesity, metabolic syndrome and bariatric surgery: A narrative review / W. Jia // Journal of diabetes investigation. 2020. - Vol. 11 (2). - Vol. 294.

\section{REFERENCES}

1. Babak, O.Ya., \& Andreeva, A.O. (2013). Hormonalni zminy v zhyrovii tkanyni khvorykh na hipertonichnu khvorobu y ozhyrinnia [Hormonal changes in adipose tissue of patients with hypertension and obesity]. Ukrainskyi terapevtychnyi zhurnal Ukrainian Therapeutic Journal, 1, 63-67 [in Ukrainian].

2. Marusyn, O.V., \& Bocyurko, V.I. (2012). Ozhyrinnia ta leptynorezystentnist [Obesity and leptin resistance]. Halytskyi likarskyi visnyk - Galician Medical Bulletin 19 (1), 155-157 [in Ukrainian].

3. Bacha, F., Saad, R., Gungor, N., \& Arslanian, S.A. (2004). Adiponectin in youth, relationship to visceral adiposity, insulin sensitivity, and beta-cell function. Diabetes Care, 27 (2), 547-552.

4. Baltasar, A., Serra, C., Pérez, N., Bou, R., Bengochea, M., \& Ferri, L. (2005). Laparoscopic sleeve gastrectomy: a multi-purpose bariatric operation. Obesity Surgery, 15 (8), 1124-1128.

5. Ebinc, H., Ozkurt, Z.N., Ebinç, F.A., Yilmaz, M., \& Caglayan, O.
10. Effect of left gastric artery embolization on obesity and ghrelin/leptin levels in pigs / H. Liu, X. Li, R. Chen [et al.] // American Journal of Translational Research. - 2021. - Vol. 13 (5). - P. 5368.

11. Metabolic syndrome and reproduction / F. Lotti, S. Marchiani, G. Corona, M. Maggi // International Journal of Molecular Sciences. - 2021. - Vol. 22 (4). - P. 1988.

12. Left gastric artery embolization for obesity treatment: a systematic review and meta-analysis of human and animal studies / M. Mizandari, Keshavarz, T. Azrumelashvili [et al.] // Abdominal Radiology. - 2021. - P. 1-12.

13. Modeling of metabolic syndrome of different genesis in experimental animals (guidelines). State Institution; Institute of Endocrine Pathology. V. Ya. Danilevsky of the National Academy of Medical Sciences of Ukraine. - Kharkiv; 2019. - 10 p.

14. Bariatric surgery for metabolic syndrome in obesity / X. Shuai, K. Tao, M. Mori, T. Kanda // Metabolic Syndrome and Related Disorders. - 2015. - Vol. 13 (4). - P. 149-160.

15. Changes in ghrelin levels following bariatric surgery: review of the literature / K. Tymitz, A. Engel, S. McDonough [et al.] // Obesity Surgery. - 2011. - Vol. 21 (1). - P. 125-130.

16 . Williams D. L. Leptin regulation of the anorexic response to glucagon-like peptide-1 receptor stimulation / D. L. Williams, D. G. Baskin, M. W. Schwartz // Diabetes. - 2006. - Vol. 55 (12). - P. 3387-3393.

17. Left gastric artery embolization in obese, prediabetic patients: a pilot study / M. M. Zaitoun, M. A. A. Basha, F. Hassan // Journal of Vascular and Interventional Radiology. - 2019. - Vol. 30 (6). - P. 790-796.

(2008). Adiponectin and insulin resistance in obesity-related diseases. Journal of International Medical Research, 36 (1), 71-79. 6. Fu, Y., Luo, N., Klein, R.L., \& Garvey, W.T. (2005). Adiponectin promotes adipocyte differentiation, insulin sensitivity, and lipid accumulation. Journal of Lipid Research, 46 (7), 1369-1379. 7. Garber, A.J. (2004). The metabolic syndrome. Medical Clinics, 88 (4), 837-846.

8. Higa, K., Ho, T., Tercero, F., Yunus, T., \& Boone, K.B. (2011). Laparoscopic Roux-en-Y gastric bypass: 10 -year follow-up. Surgery for Obesity and Related Diseases, 7 (4), 516-525.

9. Jia, W. (2020). Obesity, metabolic syndrome and bariatric surgery: A narrative review. Journal of Diabetes Investigation, 11 (2), 294.

10. Liu, H., Li, X., Chen, R., Liu, D., \& Tong, C. (2021). Effect of left gastric artery embolization on obesity and ghrelin/leptin levels in pigs. American Journal of Translational Research, 13 (5), 5368. 


\section{ЕКСПЕРИМЕНТАЛЬНІ ДОСЛІДЖЕННЯ}

11. Lotti, F., Marchiani, S., Corona, G., \& Maggi, M. (2021). Metabolic Syndrome and Reproduction. International Journal of Molecular Sciences, 22 (4), 1988.

12. Mizandari, M., Keshavarz, P., Azrumelashvili, T., Yazdanpanah, F., Lorzadeh, E., Hosseinpour, H., ... \& Sadabad, F.E. (2021). Left gastric artery embolization for obesity treatment: a systematic review and meta-analysis of human and animal studies. Abdominal Radiology, 1-12.

13. Modeling of metabolic syndrome of different genesis in experimental animals (guidelines). State Institution. Institute of Endocrine Pathology. V. Ya. Danilevsky of the National Academy of Medical Sciences of Ukraine. Kharkiv 2019; 10.

14. Shuai, X., Tao, K., Mori, M., \& Kanda, T. (2015). Bariatric

surgery for metabolic syndrome in obesity. Metabolic Syndrome and Related Disorders, 13 (4), 149-160.

15. Tymitz, K., Engel, A., McDonough, S., Hendy, M. P., \& Kerlakian, G. (2011). Changes in ghrelin levels following bariatric surgery: review of the literature. Obesity Surgery, 21 (1), 125-130. 16. Williams, D.L., Baskin, D.G., \& Schwartz, MW. (2006). Leptin regulation of the anorexic response to glucagon-like peptide-1 receptor stimulation. Diabetes, 55 (12), 3387-3393.

17. Zaitoun, M.M., Basha, M.A.A., Hassan, F., Elsayed, S.B., Farag, A.A., Amer, M., ... \& Zaitoun, N. (2019). Left gastric artery embolization in obese, prediabetic patients: a pilot study. Journal of Vascular and Interventional Radiology, 30 (6), 790-796.

Отримано 16.09.2021

Електронна адреса для листування: prodan@tdmu.edu.ua

I. YA. DZIUBANOVSKYI, A. M. PRODAN, N. A. MELNYK

I. Horbachevsky Ternopil National Medical University

\section{SURGICAL CORRECTION OF ADIPOKINE AND GRELIN LEVEL IN RATS WITH METABOLIC SYNDROME}

The aim of the work: to investigate the level of adipokines and ghrelin in the body of experimental animals with simulated metabolic syndrome after surgical correction of different types of bariatric interventions.

Materials and Methods. The study was performed on 40 white male Wistar rats weighing 200-250 g (aged 9-10 weeks), which were kept in standard vivarium conditions. The main group of rats $(n=56)$ were fed a high-fat diet (over $60 \%$ energy from fats) for 16 weeks. After that, they were divided into groups according to the type of surgical intervention: sleeve gastrectomy, Roux-en-Y gastric bypass, ligation of the left gastric artery. In the postoperative period (14 days and 1 place) the concentration of adiponectin, leptin and ghrelin were assessed. Results and Discussion. Surgical treatment of obesity reduces ghrelin and leptin levels and increases adiponectin levels in all study groups of animals with simulated metabolic syndrome. However, in the group of rats that underwent ligation of the left gastric artery normalization of adipokines (leptin and adiponectin) and ghrelin were the best and statistically significant for metabolic syndrome group, both at day 14 and after 1 month after surgery on all comparative indicators $(\mathrm{p}<0.05)$.

Key words: bariatric interventions; ghrelin; leptin; adiponectin; metabolic syndrome. 